


\title{
A SZAKKÉPZÉS INTÉZMÉNYIRÁNYÍTÁSI RENDSZERÉNEK STRUKTURÁLIS FELÉPÍTÉSE A MINTZBERG-MODELL TÜKRÉBEN
}

\begin{abstract}
THE STRUCTURE OF THE INSTITUTIONAL GOVERNANCE SYSTEM OF VOCATIONAL EDUCATION AND TRAINING IN THE LIGHT OF THE MINTZBERG MODEL
\end{abstract}

STOMP Ágnes, MÓRÉ Marianna

Kulcsszavak: intézményirányitási rendszer strukturális felépitése, közszolgálati sz̨ervezeti modellek, szakeképrési rendszer

Keywords: the structure of the institutional governance system, public service organizational models, system of vocational education and training

JEL kód: I28, L31 


\section{ÖSSZEFOGLALÓ}

A rendszerváltást követöen az állami iskolai rendszerü szakeképzést folytató oktatási intézmények belyi, megyei önkormányzatok, ezt követöen Térségi Integrált Szakképzó Kö̈ppontok, majd a Megyei Intérményfenntartó Körpont és végül a Klebelsberg Intézquényfenntartó Kö:pont fenntartásában müködtek a 2015. évi LXVI. squkeképrési törvény megalkotásáig. Az üj szakkéṕpési törvény a szakképzés intézményrendszerét teljes mértékben átalakitotta és a szakkép zó intézmények új intézményirányitási gyakorlatát vezette be egy teljesen üj strukturális felépitésben. Tanulmányunk célja a jelenleg érvényben lévó szakképzési rendszer intézményirányitásának vizsgálata, amely kizárólag az intézményirányitás szerkeezeti átalakitásának bemutatására fókuszál. Célunk feltárni a közelmúltban történt oktatásirányitási változásokat a szakeképrésben, különös tekintettel a szakekép rési centrumok megjelenéséhez kapcsolódó szerkezzeti átalakulásokra koncentrálva. Az intézményirányitási rendszer szerkezeti átalakitását a szakeképzésért és felnoöttkép zésérét felelós miniszter által alapitott és az. Innovációs és Technológiai Minisztérium által fenntartott szakeépzési centrumok és az azokhoz kapcsolódó intézmények, irányitó szervezetek esetében vizsgáljuk. Az intézményirányitás törvényi rendelkezéseinek értelmezésével és azok dokumentumelemrésével megalkotjuk a szakkeép zés intézményirányitási struktúráját, amely jól tükrözi a szakképrési centrumoknak és szakképrö iskoláknak a szakképzés intézményirányitási rendszerében betöltött helyét. A szervezeti struktúrát a közszolgálati szervez̨etek szelktor sz̨intü szervezeti modelljeivel vetjük össz̨e, annak érdekében, hogy modellszintü összehasoniltást tehessünk. Mivel a szervezeti struktúra nem alkalmas arra, hogy a gyakorlatban müködö szervezęti egységek számát szimbolizálja, ezért a szervezeti struktúrának megfelelo" irányitási adatokat a szakeképzési centrumok és szakképró intézzények esetében a leiró statisz̧tikai módszer segitségével mutatjuk be.

\section{SUMMARY}

After the change of regime, the educational institutions providing vocational training in the public school system operated in the maintenance of local and county governments, then of the Regional Integrated Vocational Training Centre, then of the County Institution Maintenance Centre and finally of the Klebelsberg Institution Maintenance Centre, until the enactment of the 2015 LXVI. Vocational Training Act. The new Vocational Education and Training Act has completely reformed the institutional system of vocational education and training (VET) and introduced a new institutional governance practice of VET institutions in a completely new structure.

The aim of our study is to examine the institutional governance of the current vocational education and training system, which focuses solely on the presentation of the structural transformation of 
institutional governance. Our aim is to explore the recent changes of the educational governance in the vocational education and training system, focusing in particular on the transformations associated with the emergence of the Centers of Vocational Training. We examine the transformation of the institutional governance system in the case of Centres of Vocational Training established by the Minister responsible for vocational education and training and maintained by the Ministry of Innovation and Technology, and in the case of related institutions and governing bodies. By interpreting the legal provisions of the institutional governance and analysing these documents, we create the institutional governance structure of the vocational education and training system, which reflects the position of the Centres of Vocational Training and the Vocational Training Institutions in the institutional governance system of vocational education and training. We compare the organisational structure with the sector-level organisational models of public service organisations in order to make a model-level comparison. As the organisational structure is not suitable to symbolise the number of organisational units operating in practice, management data corresponding to the organisational structure are presented using the descriptive statistical method for Centres of Vocational Training and Vocational Training Institutions.

\section{BEVEZETÉS}

A társadalmi és gazdasági fejlődés, átalakulás szükségszerú következményei a szervezetekre gyakorolt változás, változtatási kényszer (Benedek, 1998). A változó környezeti feltételek különböző szervezeti struktúrákat igényelhetnek. Az egyre csökkenő pénzügyi források és a külső környezeti szereplők által támasztott egyre nagyobb elvárások következtében az oktatási szervezetek jelentős kihívásokkal szembesülnek. Ezek a külső hatások a hosszú távú fenntarthatóságot és a sikert is nagymértékben befolyásolják (Dennison, 2018; Roper \& Whitt, 2016), ezért az oktatási szervezeteknek folyamatosan át kell alakítaniuk struktúráikat, folyamataikat és gyakorlataikat, hogy megfeleljenek a kihívásoknak. Ebből a szempontból azt mondhatjuk, hogy a szervezeti változás a siker receptjének alapvető összetevője az oktatási menedzsmentben (Palumbo \& Manna, 2019). Hazánkban a szakképzés területén az elmúlt harminc évben jelentős változások mentek végbe, amely a szakképzés intézményrendszerének átalakulási folyamataiban is megmutatkozott. A szakképző intézmények több fenntartó váltáson mentek keresztül, végül 2015. júliusától a Szakképzési Centrumok létrehozásával az iskolarendszerủ szakképzés-irányítás új fejezete kezdődött el az új irányítású szervezeti struktúrában. 


\section{KUTATÁSMÓDSZERTAN}

A tanulmány a jelenleg érvényben lévő szakképzési rendszer intézményirányításának szerkezeti felépítését vizsgálja a Mintzberg model tükrében. Elemezésük kiindulási pontjaként azért döntöttünk a Mintzberg modell mellett, mert az a szervezetek olyan értelmezésém alapul, amely a belső működési módjának főkuszba helyezése mellett a szervezeteket szélesebb kontextusban is elhelyezi. Az intézményirányítási rendszer strukturális felépítéséta szakképzésért és felnőttképzésérét felelős miniszter által alapított és az Innovációs és Technológiai Minisztérium által fenntartott szakképzési centrumok és az azokhoz kapcsolódó intézmények, irányító szervezetek esetében vizsgáljuk. Írásunk a dokumentumelemzés és adatelemzés módszerére épül, az adatokat a leíró statisztikai módszerekkel vizsgáltuk. A pontos helyzetkép bemutatása miatt áttekintésre kerültek a kapcsolódó törvények, rendeletek.

Kutatási módszerként a dokumentumelemzést választottuk, amely alkalmas oksági összefüggések és összehasonlító elemzések készítésére. A dokumentumelemzés a dokumentumok áttekintésére és értékelésére szolgáló szisztematikus eljárás. A kvalitatív kutatás más analitikai módszereihez hasonlóan a dokumentumelemzés is megköveteli az adatok, információk vizsgálatát és értelmezését annak érdekében, hogy értelmet nyerjenek, és empirikus ismereteket fejlesszenek ki (Corbin \& Strauss, 2008; Rapley, 2007; Bowen, 2009). Dokumentumként tekintettünk a szakképzés-irányítás új intézményrendszerének létrehozásáról, fenntartásáról, múködéséről rendelkező törvények, rendeletek dokumentumaira. Ezen dokumentumok elemzését követően a jelenleg érvényben lévő szakképzés-irányítás intézményrendszerének szervezeti struktúráját, organogramját alkottuk meg. Ezt a szervezeti struktúrát összevetve a szakirodalom által meghatározott közszolgálati szervezetek szektor szintủ szervezeti modell típusokkal megállapíthatóvá vált az a szervezeti modell, amelynek megfelelően a jelenlegi szakképzés-irányítás folyik.

A szakképzési centrumok és szakképző intézmények vonatkozásában a Szakképzés Információs Rendszer (SZIR) adatbázis nyilvánosan elérhetô adatai adták az adatelemzés alapját. Az adatgyújtés a szakképzési centrumok és szakképző intézmények esetében 2021. évre vonatkozóan történt a Szakképzés Információs Rendszer adatbázis által közétett adatokat felhasználva. Az adatbázisból leválogattuk az Innovációs és Technológiai Minisztérium által fenntartott szakképzési centrumokat és az azokhoz tartozó szakképző intézményeket, amelyeket excel táblában gyújtöttünk össze és ennek alapján végeztük el a statisztikai elemzésünket. 


\section{SZAKIRODALOM FELDOLGOZÁS}

\section{Szervezet fogalma}

A szervezet olyan emberek csoportja, akik együtt dolgoznak egy cél elérése érdekében a saját környezetükből szerezhető források felhasználásával (Rainey, 2009). A szervezetek olyan rendszerek, amelyeket emberek és tárgyak alkotnak, tartós célt követnek, formális struktúrával és célszerű szabályokkal rendelkeznek (Dobák \& Antal 2018). Társadalmi és gazdasági megközelítésből kiindulva a szervezet olyan tudatosan kiépített rendszer, amely a társadalmi és gazdasági folyamatok realizálásának feltételeit és kereteit biztosítja (Pierog \& Szabados, 2015). Barnard (1938) a szervezet fogalmi meghatározását a vezetés oldaláról közelíti meg, miszerint a szervezet nem más, mint két vagy több személy tudatosan irányított tevékenységeinek vagy erőinek rendszere (Barnard, 1938).

A szervezeteket különböző funkciók ellátása céljából hozzák létre, amelyben a szervezetek tagjai saját elhatározásukból vesznek részt a szervezet feladatainak elvégzésében, annak céljainak megvalósításában (Móré \& Kozák, 2015). Csepeli (2015) szerint a szervezetek által ellátott társadalmi funkciók sajátossága, hogy azokat a társadalom tagjai külön-külön nem képesek ellátni. A szervezetekben a tagok egymással együttmúködve cselekszenek, amelynek eredményeként célirányos eredményességi többlet keletkezik.

A szervezetek osztályozásának számos módja létezik. Strukturális megközelítésből két szervezeti csoportot különböztetünk meg. Az informális szervezet szabályozatlan együttmúködéseket és folyamatokat, spontán szerveződő kapcsolatokat jelent. A formális szervezet rögzített szervezeti szabályok szerint múködik, amely formákban megjelenített részlegekből, munkakörökből, hatáskörökből és folyamatokból áll (Móré \& Kozák, 2015).

Mintzberg (1996) négy típusú szervezetet különböztet meg négy tulajdonosi forma szerint. A magántulajdonban lévő szervezetete tulajdonosai magánszemélyek vagy a piacon forgalmazott részvények tulajdonosai. A köztulajdonban lévó vagy állami tulajdonú szervez̨etek az állampolgárok képviseletében járnak el. A sqövetkezeti tulajdonú sžervezetek beszállítóik, ügyfeleik vagy alkalmazottaik irányítása alatt állnak. Mintzberg (1996) a negyedik típusú szervezeteket nem tulajdonolt szervezetekenek nevezi, amelyeket saját választott igazgatótanácsai irányítanak.

Csepeli (2015) a szervezetek két fó típusát határozza meg a tulajdonlás és a haszon jellege szerint. Az egyik típus a köztulajdonban lévố sžervezetek, amelyeknek célja a közösség szolgálata. A szerző a köztulajdonban lévő szervezeteket tovább csoportosítja termelő és szolgáltató szervezetekre, ez utóbbit közszolgálati szervezeteknek nevez, amelyek költségvetését az önkormányzat vagy az állam 
határozza meg. A szervezetek másik típusa a tulajdonlás és haszon jellege szerint a magántulajdonban lévó szervezetek, amelyekben a tulajdonosok célja a minél nagyobb pénzben kifejezett haszon szerzése. Csepeli (2015) szerint a szervezetek osztályozásának egy másik, lehetséges módja a szervezetek céljai szerinti osztályozás. Eszerint a következő szervezet típusokat különbözteti meg: Gazdasági

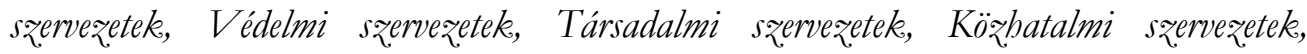
Közszolgálati szervezetek, Egészségügyi és szociális intézmények, Vallási szervezetek. Szúkítve a fogalmat az oktatási szervezetek meghatározására Keczer (2014) alapvetően háromféle oktatási szervezetet különböztet meg: közintézmények (állami iskolák és felsőoktatási intézmények, regionális képzési központok), kereskedelmi szervezetete (pl. korlátolt felelősségú társaság, részvénytársaság) és nonprofit szervezetek (pl. alapítványok). Úgy véljük, hogy egy új típusú oktatási szervezetként definiálhatjuk a közelmúltban megalapított alapitványokat, amelyek az egyetemeket múködtetik.

\section{Intézmény fogalma}

Az intézmény olyan társadalmi vagy állami szervezet, amelyet közösségi célra létesítenek, személyi keretekkel rendelkezik és feladata az egyének cselekedeteinek irányítása és befolyásolása (Móré \& Kozák, 2015). Weber (1987) szerint az intézmény olyan szervezet, amelynek tervszerúen lefektetett rendje van, amit minden cselekvésre rákényszerítenek. Ennek értelmében intézménynek tekinti a vállalatokat, önkormányzatokat, egyetemeket, oktatási szolgáltatásokat nyújtó szervezeteket. Az intézmény fogalmának széles körben elfogadott különböző értelmezéseit Farkas (2007) összegezte, amely szerint az intézmény jelentheti: az elvárások-, szabályok sajátos rendszerét, a viselkedés megfigyelhető szabályszerűségeit, a beállítottságok-, értelmezési hajlandóságok valószínűségét, a csoportot vagy a szervezetet, a társadalom valamely szféráját vagy alrendszerét. Farkas (2010) az intézmények három fó típusát különbözteti meg: közösségi, társadalmi és testiségi intézményeket. Társadalmi intézménynek nevezi az olyan intézményeket, amelyek az egyének számára az intézmények által biztosított cselekvési lehetőségek és képességek a szükségletkielégítés eszközeit képezik. Ilyen intézményeket találunk a szervezett oktatás és tanulás területén. A gazdaságitársadalmi cselekvések formalizált tevékenységei az üzleti, az állami (közszolgálati)

és a nonprofit szférában zajlanak. E három szféra szervezeteit a következő táblázat összefoglalóan tartalmazza (Antal et al., 2011): 
1. táblázat. A gazdasági-társadalmi szektorok szervezetei és céljai

\begin{tabular}{|l|l|l|}
\hline $\begin{array}{c}\text { Gazdasági-társadalmi } \\
\text { szektor }\end{array}$ & \multicolumn{1}{|c|}{ Szervezet } & \multicolumn{1}{c|}{ Cél } \\
\hline Üzleti szektor & Vállalkozások, vállalatok & Nyereségszerzés \\
\hline $\begin{array}{l}\text { Állami (közszolgálati) } \\
\text { szektor }\end{array}$ & $\begin{array}{l}\text {-Törvényhozó, végrehajtó } \\
\text { és igazságszolgáltatási } \\
\text { intézmények } \\
\text {-Honvédelmi szervek } \\
\end{array}$ & $\begin{array}{l}\text { Kollektív igények } \\
\text { kielégítése }\end{array}$ \\
& $\begin{array}{l}\text {-Köznevelézményei szakképzés } \\
\text {-Egészségügy intézményei }\end{array}$ & \\
\hline Nonprofit szektor & $\begin{array}{l}\text { Civil szervezetek } \\
\end{array}$ & $\begin{array}{l}\text { Jótékonyság, } \\
\text { közhasznúság }\end{array}$ \\
\hline
\end{tabular}

Forrás: Saját szerkesztés Antal et al., 2011 alapján

Keczer (2014) különbséget tesz az oktatási intézmények és azon szervezetek között, amelyek termékeket állítanak elő. Úgy véli, hogy az oktatási intézmények azok a szervezetek, amelyek szolgáltatást nyújtanak és az alaptevékenységük az oktatás (Keczer, 2014).Az imént összefoglalt szakirodalmi fogalom meghatározásokat összefüggésbe állítva a magyar szakképzési rendszerrel, megállapítjuk, hogy az elemzésünk tárgyát képező iskolarendszerű szakképző intézmények a szakirodalmi osztályozási szempontok szerint a közszolgálati szektor csoportjába tartoznak, tehát közszolgálati szervezetnek tekinthetők és a jelenleg múködő szakképző intézményeket a közszolgálati szervezet „,köznevelés és szakképzés intézményei" intézménytípusba soroljuk, amelyek célja a társadalom oktatási igényeinek kieglégítése. Ezen intézményeket formális szervezeteknek tekintjük, hiszen a szakképzési törvényben foglaltaknak megfelelően múködnek.

Összefoglalva, az állami iskolarendszerű szakképző intézményeket olyan állami tulajdonú oktatási intézménynek határozzuk meg, amelyek tevékenységük szerint a közszolgálati szektorban múködő közszolgálati szervezetek és alapfeladatuk szakképzési szolgáltatás nyújtása a társadalom tagjai számára formális szervezeti kereteken belül. 


\section{Közszolgálati szervezeti modellek}

A közszolgálati szervezetek szervezeti modelljeit az üzleti modellek adaptálásával és kiegészítésével határozza meg a szakirodalom. Azonban Mintzberg (1996) közszolgálat számára kifejlesztett tipizálása egyedülállónak számít a szakirodalomban, amely a közszolgálati szervezeteket a belső struktúrájukon és múködésükön túl szektor szinten értelmezi. A közszolgálati szervezetek szektor szintű értelmezéséhez a „szuperstruktúra” és „,mikorstruktúra” fogalmakat alkotta meg. A szuperstruktúra a szolgáltatások tervezését és ellenőrzését valósítja meg, míg a mikrostuktúra a szolgáltatások operatív megvalósítását végzi.

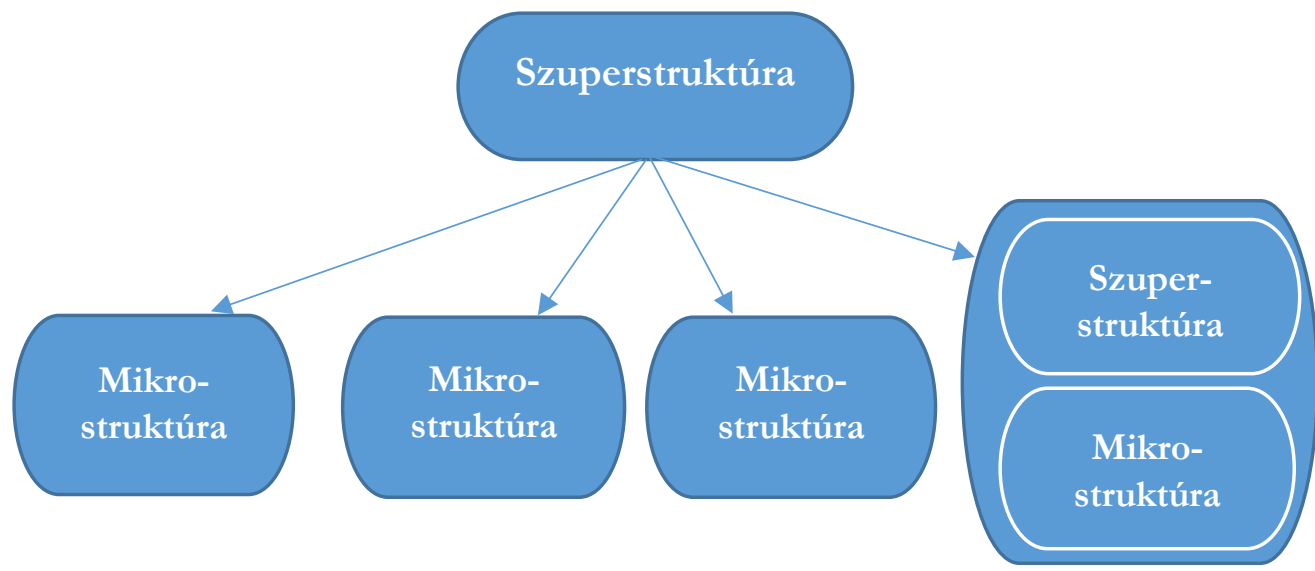

1. ábra. Mintzberg közszolgálati szervezeti modellje: szuper- és mikrostruktúra

Forrás: Saját szerkesztés Antal et al., 2011 alapján

Az 1. ábrán látható, hogy egy szuperstruktúrán belül több, köztes, hierarchiába rendezhetô szuperstruktúra is kiépülhet. Ez a gyakorlatban azt jelenti, hogy a köztes szuperstruktúra a mikrostruktúrák szintjén elhelyezkedő intézmények egységes irányítását végezheti a hierarchia csúcsán álló szuperstruktúra irányitása és kontrollja mellett. A különböző szervezeti modellek értelmezhetők mindkét struktúra, valamint ezek egymáshoz való viszonya szintjén is. Ez a modell a szuperstruktúra és mikrostruktúra összefüggéseit és egymáshoz való kapcsolódását jól szimbolizálja (Antal et al., 2011; Mintzberg, 1996).

Mintzberg (1996) a közszolgálati szervezetek öt olyan szektorszintű modelljét alkotta meg, amelyek képesek kezelni az ezen típusú szervezetek komplexitását. Az öt szervezettípus közös jellemzője, hogy azok mindegyikét külön-külön az irányító szervezet ellenőrző hatóságának vagyis a szuperstruktúrának, valamint a 
szervezeti egységek tevékenységének vagyis a mikrostruktúrájának megszervezésének sajátos módja jellemzi.

A közszolgálati szervezetek szektorszintủ modelljeit az alábbiakban röviden ismertetjük:

- A gépmodell szerint a szervezetet olyan „gépezetnek” tekintik, amelyet szabályok, elôírások és szabványok uralnak, amelyek mind a szuper - és mikrostruktúra szintjén érvényesek. Minden egyes szervezeti egység ellenőrzi az alkalmazottait és tevékenységeiket, ahogy magát a szervezeti egységet pedig a központi apparátus. A modell biztosítja a következetes politikát és megbízhatóságot, de rugalmatlan és hiányzik belőle az egyéni kezdeményezések iránti érzékenység. A funkcionális szervezet (gépi bürokrácia) logikájára épül.

- A bálózatmodellt a gépmodell ellentetjének tekinti, amely lazán szerveződô, interaktív és informális modelltípus. A szervezetet egyetlen összefonódó rendszernek tekinti, amelyet elsősorban a felmerülő problémák megoldására alakítottak ki. A mikrostruktúra szintjén a munka projektek köré szerveződik. Az egyes projektek egymással összefüggő projektek hálójában múködnek.

- A teljesitménykontroll modellben a tervezésen és teljesítményen van a hangsúly. Ennek a modellnek az a célja, hogy a szervezetet a gazdasági, üzleti szervezetekhez hasonlóvá tegye. A teljes szervezet „vállalkozásokra” van felosztva, amelyek teljesítménycélokat kapnak, amelyekért a vezetőik felelősséggel tartoznak. Ez a kényszer megerôsíti a hierarchikus irányítást a mikrostruktúra szintjén, amelynek a végső hatása a régi gépmodell megerősitése. Ez a modell a divizionális szervezet közszolgálati adaptációja.

- A virtuális modellt a teljesítménykontroll modell szélsőséges esetének nevezi. A mikrostruktúra szintjén lévő szervezetek, intézmények már nem a közszolgálati szektor része, minden ilyen jellegű tevékenység a magánszektorban történik. A szuperstruktúrák feladata pedig már csak az, hogy biztosítsák a közszolgáltatások üzleti szervezetek által történő ellátását.

- A normakontroll modell nem a rendszerekről és számokról szól, hanem mindinkább az attitüdök számítanak. Az irányítás normatív, vagyis értékekben és meggyőződésekben gyökerezik. A szuperstruktúra feladata az alkalmazottai kiválasztása és az elvi irányítás. Az alkalmazottakat értékeik és attitúdjeik alapján és nem a végzettségük alapján választják ki. A szervezeten belül minden tag megosztja a felelősséget egymással és úgy véik, hogy a vezetők megbíznak bennük és támogatják őket. Az alkalmazottak teljesítményeit a tapasztaltabb kollégák és a szolgáltatások haszonélvezői ítélik meg. A mikrostruktúrák egyes egységei 
horizontálisan elkülönülnek, de a szuperstruktúra vertikális irányítása kevésbé hierarchikus (Antal et al., 2011; Mintzberg, 1996).

Mintzberg (1996) úgy véli, hogy nem létezik egy legjobb modell. A közszolgálati szektorban mindegyik modelltípus előfordul, de a legtipikusabb a gépmodell előfordulása. Ámbár megjegyzi, hogy nagy szükségünk lenne egy jelentős hangsúlyeltolódásra a normatív modell felé, mivel az emberi odaadást semmi sem helyettesítheti. Úgy véli, hogy emberi elkötelezettség nélküli szervezet, olyan mint egy lélek néküli ember, amelyből hiányzik az életerő. Ez a következtetés különösen érvényes az ügyfélközpontú szakmai szolgáltatásokra, mint például az egészségügy és az oktatás, amelyek soha nem lehetnek jobbak, mint az azokat nyújtó emberek. A szakembereket meg kell szabadítani a kormányzati bürokrácia közvetlen irányítása alól (Mintzberg, 1996).

Összegezve Mintzberg közszolgálati szektorszintú modelljének jellemzőit, megállapítjuk, hogy ez a modell a szuperstruktúra és mikrostruktúra fogalmak megalkotásával lehetővé teszi a vizsgálatunk tárgyát képező szakképzési rendszer intézményirányításának elemzését strukturális szempontból, hiszen a szakképző intézmények, mint közszolgálati szervezetek működésének értelmezését szektor szinten biztosítja.

\section{Tanügyirányítás a szakképzésben Magyarországon}

A hazai szakirodalom a közigazgatásban a menedzsment tevékenységet intézményirányításként, szervezésként értelmezi. Ez a szemlélet magát a vezetést alárendeli a szervezésnek, az intézményirányításnak és a szervezeti struktúráknak (Metz, 2020; Antal \& Dobák, 2016; Bakacsi, 2006). A fenti fogalmak értelmezése egyértelmúen alátámasztja azt a tényt, hogy a menedzsment/irányítás és vezetés tevékenysége különböző, de mindkettő egyenrangúan fontos, nélkülözhetetlen a mai modern kori oktatási szervezetek múködésében (Bolman \& Deal, 2017).

Az oktatási rendszer irányításával kapcsolatosan a hazai szakirodalomban széles körú fogalomhasználat figyelhetô meg: oktatásirányítás, közoktatásügyi igazgatás, tanügyigazgatás, tanügyirányítás. Halász (2001) úgy véli, hogy az oktatásirányítás intézményrendszerét az oktatás feletti ellenőrzés biztosítása céljából hozták létre, amely különböző irányítási jogosítványokkal rendelkező közhatalmi szervezetekből áll és a közigazgatási-politikai rendszer és az oktatási rendszer összekapcsolását biztosítja. Az oktatásirányítással szinonim fogalomként használja a közoktatásügyi igazgatást, amelynek a közoktatási rendszerek szabályozása a feladata. Az oktatási rendszer irányítása a közoktatásügyi igazgatás szervezetén keresztül történik. Váradi (2009) a tanügyigazgatás alatt a közoktatás 
szervezését és irányítását érti. Rónay (2019) a tanügyigazgatás három típusát különbözteti meg: szűk értelemben az ágazatirányító tevékenységet jelenti, tágabb értelemben a fenntartói tevékenységet is magában foglalja, és legtágabb értelemben a közneveléssel kapcsolatos az intézményen belül és kívül egyaránt megjelentő tevékenységekre terjed ki. Mártonfi (2019) már tanügyirányításként használja ugyanezt a fogalmat, amely magában foglalja a szakterületi irányítási struktúra, a képzési struktúra és tartalom, az intézményfenntartás, a finanszírozási rendszer vagy beiskolázás kereteit. Györgyi (2019) úgy véli, hogy bár a tanügyigazgatás és tanügyirányítás fogalmának elhatárolása nem teljesen egyértelmű, mégis különbséget tesz közöttük. Györgyi (2019) a tanügyigazgatás alatt a közigazgatáshoz kapcsolódó szakigazgatás kifejezés oktatási területen használt megfelelőjét érti, amely vonatkozik az oktatás irányításában részt vevő intézményekre és a rájuk vonatkozó szabályokra, eljárásokra. Tanügyirányítás (vagy szinonimja az oktatásirányítás) magában foglalja a szakpolitikának alárendelt teljes döntéshozatali rendszert és az érdekérvényesítő csoportok tevékenységének rendszerét. A fenti fogalommeghatározásokat értelmezve megállapítjuk, hogy a tanügyigazgatás, tanügyirányítás a legtábabb értelemben magában foglalja az oktatási intézménnyel kapcsolatos, az intézményen belüli és kívüli tevékenységeket is. Míg az oktatásirányítás egy szúkebb fogalommeghatározásként különböző irányítási jogosítványokkal rendelkező szervezeteket foglal magában és azok tevékenységére utal. Az imént bemutatott fogalomakat összefüggésbe állítva a jelenlegi magyar szakképzési rendszerrel, megállapítjuk, hogy az oktatásirányítást a jelenlegi szakképzési rendszerben szakképzés irányításként említik a vonatkozó törvényekben.

\section{EREDMÉNYEK}

Elemzésünk első lépéseként a témánkhoz kapcsolódó törvények és rendeletek áttekintésével, dokumentumelemzést végeztük el. Ez segítséget adott nekünk abban, hogy a ma érvényben lévő szakképzés-irányitás szervezeti felépítését meghatározzuk, amelyből tisztán és egyértelmúen láthatjuk a fenntartónak, az NSZFH- nak, a szakképzési centrumoknak és a szakképző intézményeknek a helyét és kapcsolatrendszerét az intézményirányítási rendszerben. A dokumentumelemzés során összegzett információkat az alábbiakban közöljük. 


\section{Törvények és rendeletek}

Az állami iskolai rendszerú szakképzést folytató oktatási intézmények helyi, megyei önkormányzatok, Térségi Integrált Szakképző Központok, majd a Megyei Intézményfenntartó Központ fenntartásában múködtek a 2011. évi CXC. köznevelési törvény megalkotásáig (Mártonfi, 2016; Mártonfi, 2019). A köznevelési törvény átalakította az intézményrendszert és rendelkezett arról, hogy az iskolarendszerú szakképzést folytató iskolák nagy része a Klebelsberg Intézményfenntartó Központ fenntartásába került. Ez a rendszer rövid ideig múködött.

2015. július 12-én hatályba lépett a 2015. évi LXVI. szakképzési törvény, amely a szakképzés intézményrendszerét teljes mértékben átalakította és a szakképző intézmények új intézményirányítási gyakorlatát vezette be. A 120/2015. (V.21.) és 146/2015. (VI.12) kormányrendeletek rendelkeztek arról, hogy a korábban a Klebelsberg Intézményfenntartó Központ fenntartásában múködő állami fenntartású iskolai rendszerű szakoktatási és szakképzési feladatokat ellátó köznevelési intézmények kiválnak és 2015. július 1-jével szakképzési centrumok szervezeti formájában folytatják tovább tevékenységüket a Nemzetgazdasági Miniszter fenntartása alatt.

A szakképzés irányítás új intézményrendszerének kialakítása során a 319/2014. (XII.13.) Kormányrendelet értelmében szakképzési intézményfenntartó központként létrehozták a Nemzeti Szakképzési és Felnőttképzési Hivatalt, amely 2015. július 1-jétôl a szakképzési centrumok részeként múködő szakképző intézmények felett, mint középirányító szerv gyakorolja az irányító szervi hatásköröket. A 2015. évben született rendelkezések értelmében a Nemzetgazdasági Miniszter (ma már szakképzésért és felnőttképzésért felelős miniszter) negyvennégy szakképzési centrumot hozott létre, amelynek tagintézményei az állami iskolarendszerû szakképzés feladatait látják el.

A 2019. évi LXXX. törvény értelmében a szakképző intézmény jogi személy, amely a szakképzési alapfeladat ellátására jött létre. A szakképző intézmény a szakképzési centrum tagintézményeként múködő, a szakképzési centrum jogi személyiséggel rendelkező szervezeti egysége.

A fenntartóváltás és az azt követô intézményintegráció egy teljesen új szakképzési intézményrendszert teremtett meg, amelynek szervezeti felépítését a következő ábrán szemléltetjük: 


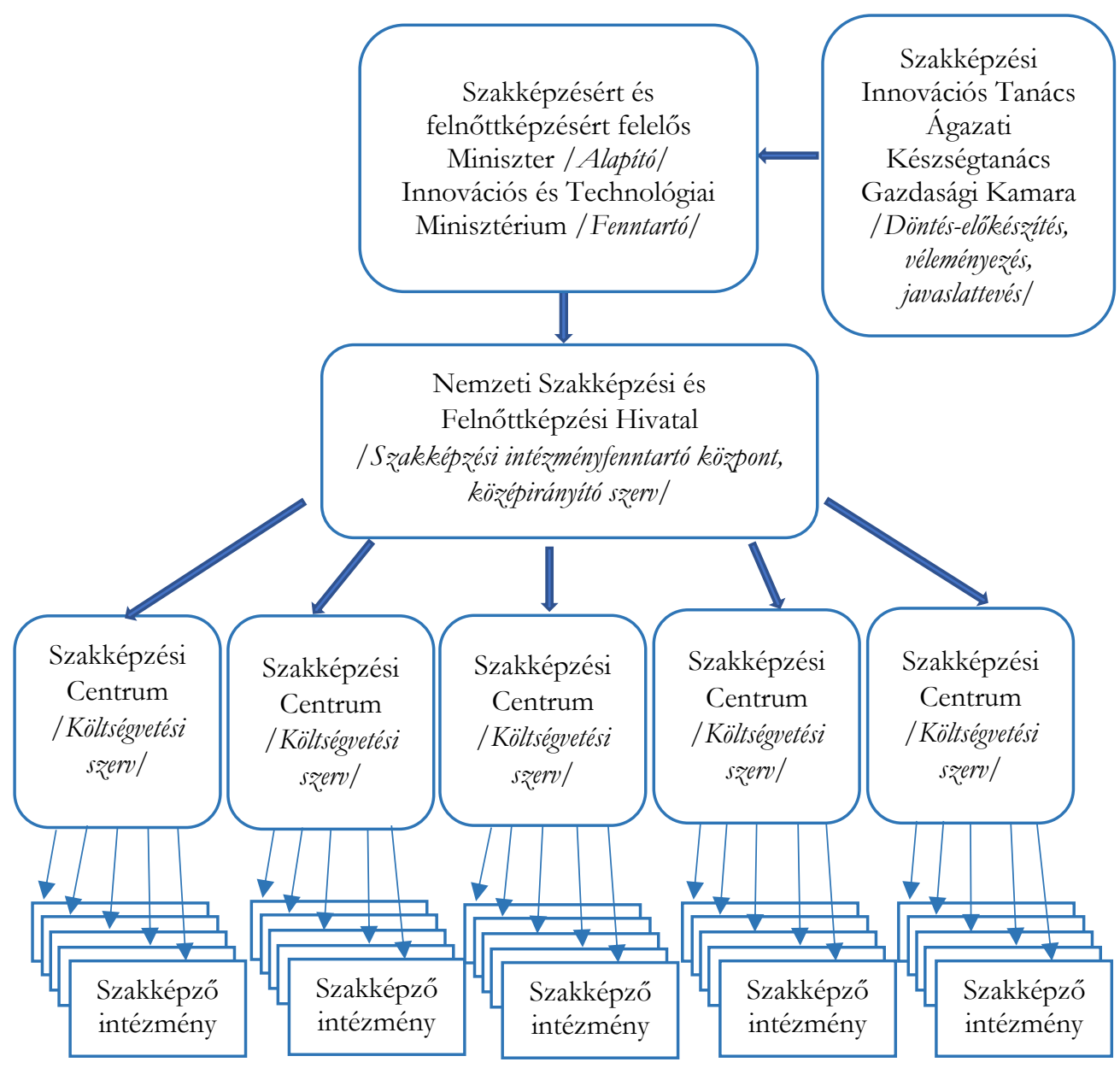

2. ábra. A szakképzés intézményirányitásának szervezeti struktúrája

Forrás: Saját szerkesztés

Az 2. ábrán szereplő szervezeti struktúra nem alkalmas arra, hogy a gyakorlatban múködő szervezeti egységek számát szimbolizálja, azonban jól szemlélteti az egyes hierarchia szinteket. Az 2. ábrát elemezve megállapítható, hogy a szakképzés intézményirányítási rendszere négy hierarchia szintből áll: fenntartó, a szakképzési intézményfenntartó - középirányító szerv, szakképzési centrum és a szakképző intézmény. A szakképzés intézményirányítási rendszerét a centralizált irányítás jellemzi. A szakképzés-irányítás gyakorlatában ez úgy nyilvánul meg, hogy a hierarchia csúcsán a szakképzésért felelős miniszter - a fenntartó - áll, aki irányítja az általa alapított szakképzési centrumot és az állam nevében gyakorolja az általa alapított szakképzési centrum részeként múködő szakképző intézmények feletti 
fenntartói irányítási hatásköröket (12/2020 (II.7) kormányrendelet). Ezen fenntartói hatáskörök nagy részét - néhány rendeletben rögzített fenntartói hatáskör kivételével - az NSZFH gyakorolja és teljesíti a fenntartó jogszabályban meghatározott kötelezettségeit. A szervezeti struktúrában a második hierarchia szinten az NSZFH áll, amely közvetlenül a szakképzésért felelôs miniszter irányítása alatt álló szakképzési intézményfenntartó központ, amely Magyarország területére kiterjedő illetékességgel rendelkezik (18/2016. (X. 12.) NGM utasítás). A harmdik hierarchia szinten a fenntartó által megalapított negyvenegy szakképzési centrum áll, amely köztes egységként közvetíti az NSZFH és a szakképző intézmények között a központ elvárásait, ellenőrzi az egységek múködését és a központ felé beszámol. A szakképzési centrumok közvetlen irányító szerve a fenntartó, illetve az NSZFH a rá átruházott hatáskörökben. A negyedik hierarchia szinten a szakképző intézmények állnak, amelyek a szakképzési centrumok tagintézményei és a centrumok szakképzési feladatellátását végző szervezeti egységei. A szakképző intézményt az igazgató a szakképzési centrum fơigazgatójának irányítása mellett vezeti. A Szakképzési Innovációs Tanács, Ágazati Készségtanács és Gazdasági Kamarák döntéselőkészítéssel, véleményezéssel és javaslattevéssel segítik a szakképzésért felelős minisztert a szakképzéssel kapcsolatos feladatainak ellátásában.

\section{Szakképzési centrumok és szakképző intézmények országos viszonylatban}

Tekintettel arra, hogy a szervezeti struktúra nem alkalmas arra, hogy a gyakorlatban múködő szervezeti egységek számát szimbolizálja, ezért ebben a fejezetben bemutatjuk a szervezeti struktúrának megfelelő irányítási adatokat Magyarországon a szakképzési centrumokra és szakképző intézményekre fókuszálva Az Innovációs és Technológiai Minisztérium fenntartásában múködő szakképzési centrumok kialakítása során a területi irányítás elve valósult meg, de nem megyei, hanem annál kisebb területi egységekre vonatkoztatva (Mártonfi, 2016). Megyénként legfeljebb három, a fővárosban pedig lefeljebb öt szakképzési centrumot hoztak létre 2015-ben. A szakképző intézmények alaptevékenységét (oktatás) földrajzi elv szerint tagolták, melyeket a területi elv szerint megyénként létrehozott egy, kettő vagy három szakképzési centrumok irányítása alá soroltak. A szakképzési centrumokat és tagintézményeiket a Köznevelés Információs Rendszerében (KIR) tartották nyilván. A szakképzésről szóló 2019. évi LXXX. törvény érvénybe lépésekor ezeket az intézményeket megszűnt státuszúvá nyilvánították a KIR- ben 2020. június 30.-ai dátummal. A szakképzési centrumok 
múködésével kapcsolatosan csekély átszervezést valósítottak meg, így például 2015-ben a fôvárosban alapított öt szakképzési centrumból a Budapesti Vendéglátóipari és Humán Szakképzési Centrum megszüntetésre került, így jelenleg négy múködik a fơvárosban. A szakképzésről szóló 2019. évi LXXX. törvény alapján a Szakképzési Információs Rendszerben (SZIR) tartják nyilván a szakképzési centrumokat és a hozzájuk tartozó szakképző intézményeket jelenleg. Az alábbi 3. ábra Az Innovációs és Technológiai Minisztérium fenntartásában múködő szakképzési centrumok és a hozzájuk tartozó szakképző intézmények számát területenként mutatja országos viszonylatban 2021-ben.

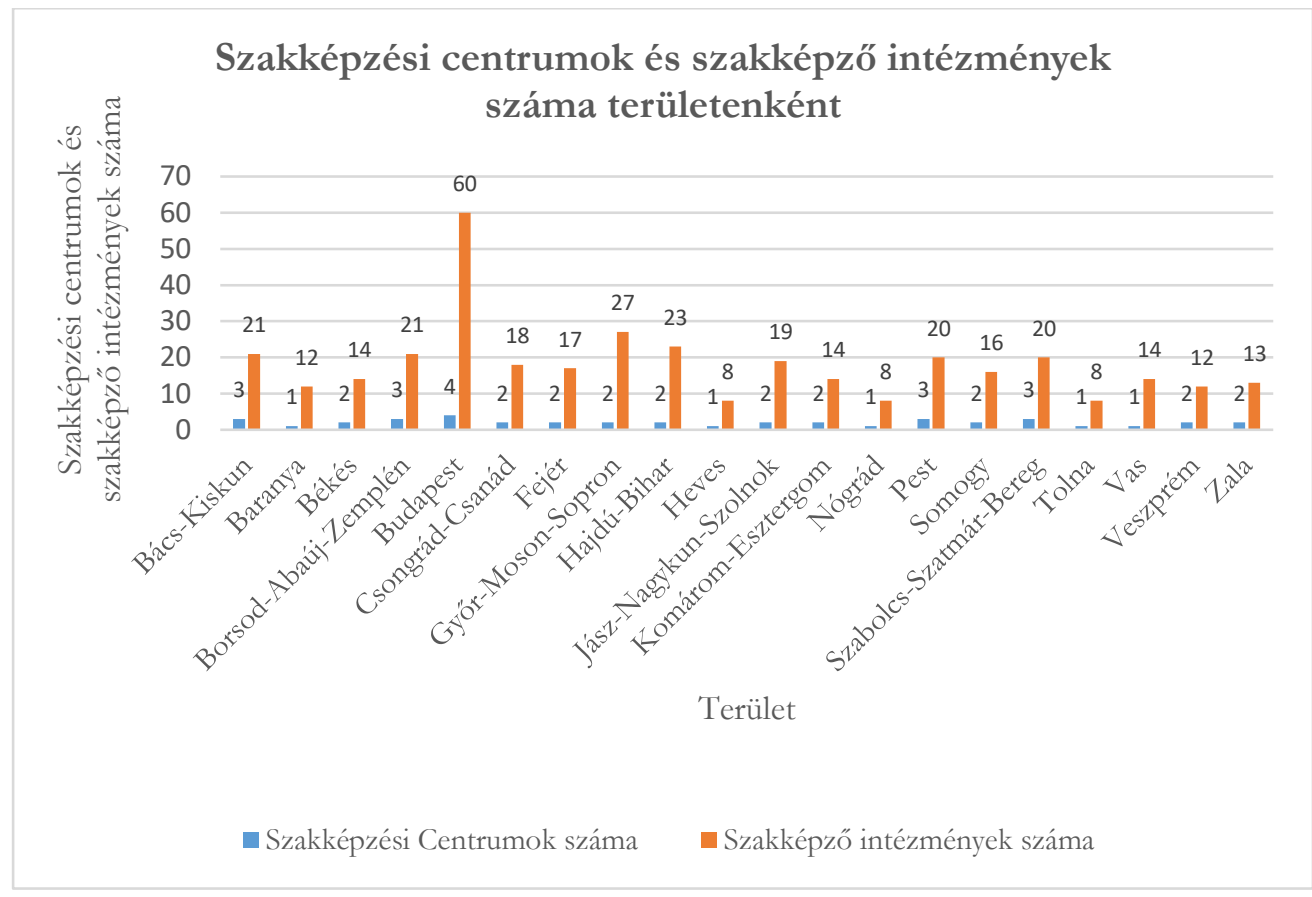

\section{3. ábra. A szakképzési centrumok és szakképző intézmények száma területenként Magyarországon 2021-ben}

Forrás: Saját szerkesztés a SZIR adatai alapján, 2021.

A 3. ábra a szakképzési centrumok és a szakképző tagintézmények számának alakulását mutatja területi megoszlásban Magyarországon. A diagram adatait elemezve, megállapítjuk, hogy a 19 megyében egy, kettő vagy három szakképzési centrumot hoztak létre a törvényi rendelkezésnek megfelelően Kivételt képez ez alól a fơváros, Budapest, amelyben négy szakképzési centrum múködik, tekintettel a nagy múködési környezetre. Budapest esetében az intézmények tematikus elv 
szerint kerültek hozzárendelésre, például műszaki, gazdasági szakképzési centrum, amelybe kifejezetten az ilyen irányultságú iskolák tartoznak. A legkevesebb, egy szakképzési centrum Baranya, Heves, Nógrád, Tolna és Vas megyékben múködik, amelyből Heves, Nógrád és Tolna megyében a legkevesebb nyolc-nyolc tagintézmény működik országos összehasonlításban. A legtöbb, négy szakképzési centrum Budapest múködési területen lett létrehozva, amely a legtöbb, összesen hatvan tagintézményt foglal magában.

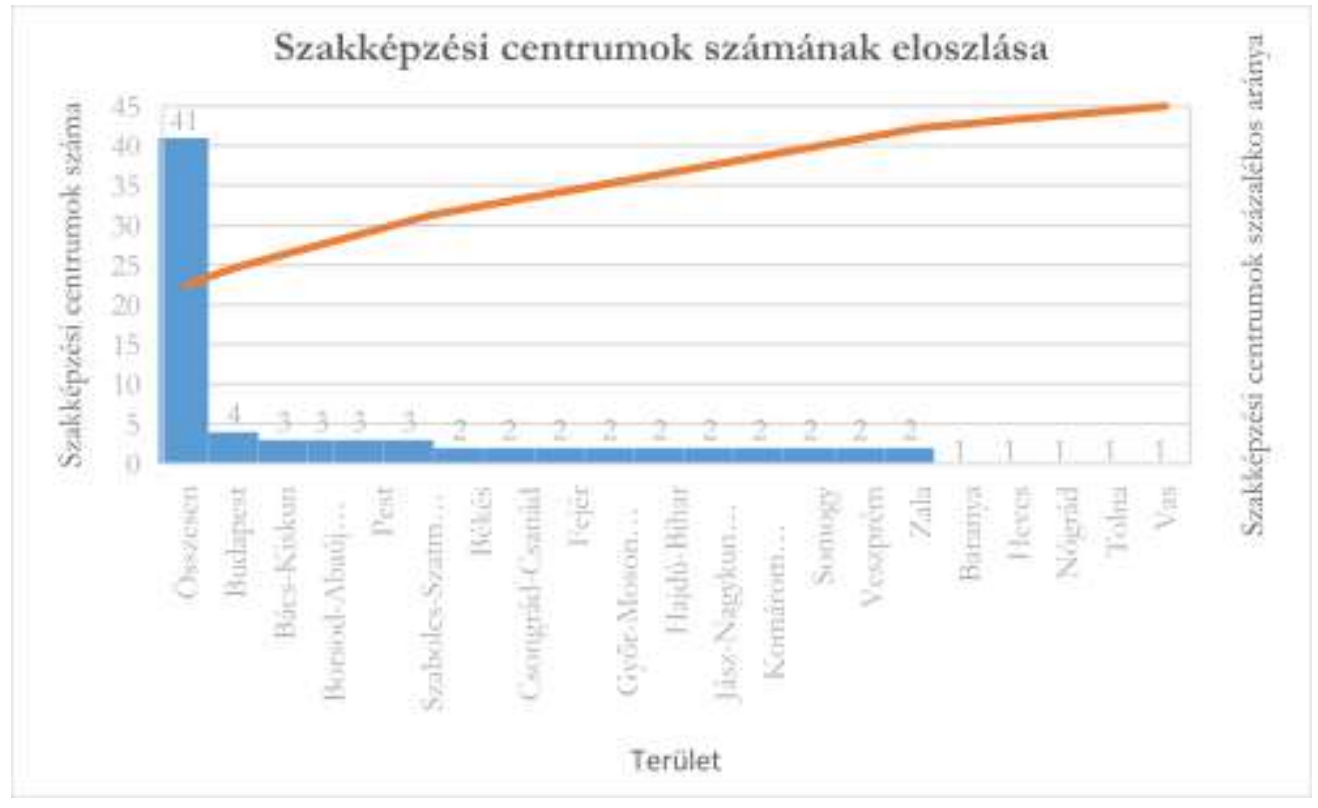

4. ábra. A szakképzési centrumok számának eloszlása Magyarországon Forrás: Saját szerkesztés a SZIR adatai alapján, 2021.

A 4. ábra a szakképzési centrumok számának eloszlását mutatja csökkenő gyakorisági sorrendben, a kumulatív vonallal a másodlagos tengelyen mutatja az egészhez viszonyított százalékarányokat. A 4. ábrát elemezve megállapítjuk, hogy szakképzési centrumok leggyakoribb eloszlása Budapest területen van, négy darab, amely 9,75\%-ot tesz ki az összes szakképzési centrumhoz viszonyított százalékban. A szakképzési centrumok legalacsonyabb gyakorisági előfordulása Baranya, Heves, Nógrád, Tolna és Vas megyében jellemző, megyénként egy-egy, amely 2,44 \%-a az összes szakképzési centrumhoz viszonyított százalékban. 
Egy szakképzési centrumra jutó intézmények száma

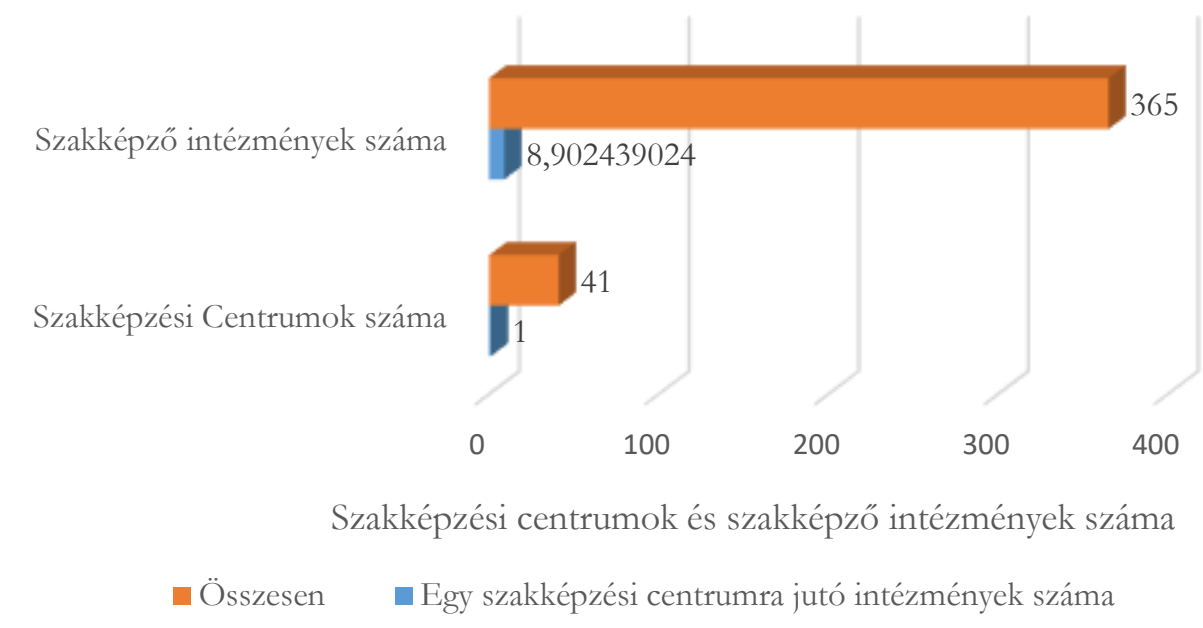

5. ábra. Egy szakképzési centrumra jutó intézmények száma Magyarországon Forrás: Saját szerkesztés a SZIR adatai alapján, 2021.

Az 5. ábrát elemezve megállapítjuk, hogy az országban az Innovációs és Technológiai Minisztérium fenntartásában összesen 41 szakképzési centrum található, amely összesen 365 szakképző intézményt foglal magában. A diagram szemlélteti, hogy egy szakképzési centrumra átlagosan 8,90 szakképző intézmény jut. Ezt jóval meghaladja Vas megye, ahol egy szakképzési centrumra 14 szakképző intézmény jut. Azonban ez az arány Budapest múködési területen a legmagasabb, ahol átlagosan egy szakképzési centrumra 15 szakképző intézmény jut.

\section{KÖVETKEZTETÉSEK}

A szakirodalomban Mintzberg (1996) által meghatározott közszolgálati szervezeti modell szektor szinten értelmezhető a szakképzés intézményirányítás gyakorlatában. A dokumentumelemzés során megalkotott intézményirányitás struktúra a szakképzésben jól szimbolizálja az egyes szervezeti egységek összefüggéseit, egymáshoz való kapcsolatukat és megfeleltethetô a Mintzbergi szuper - és mikrostruktúrának. A szakképzés intézményirányítási struktúrájának esetében a fenntartó a hierarchia csúcsán álló szuperstruktúraként értelmezhetô, amelyen belül további két köztes, hierarchiába rendezett szuperstruktúrának 
tekintjük az NSZFH-t és a szakképzési centrumokatA modell értelmében a szakképző intézményeket mikrostruktúrának tekintjük. Tekintettel arra, hogy a szervezeti struktúra nem alkalmas arra, hogy a gyakorlatban múködő szervezeti egységek számát szimbolizálja, ezért a szervezeti struktúrának megfelelő irányítási adatokat a szakképzési centrumok és szakképző intézmények esetében a leíró statisztikai módszer segítségével mutattuk be. A szakképzési centrumok és szakképző intézmények számának területi megoszlását számba véve kijelentjük, hogy a köztes szuperstruktúra szintjén negyvenegy szakképzési centrum, míg a mikrostruktúrák szintjén 364 szakkképző intézmény múködik jelen gyakorlatban. A struktúrát a feladatvégzés szempontjából elemezve megállapítjuk, hogy a szuperstruktúrának tekinthetô fenntartó, az NSZFH és a szakképzési centrum a szolgáltatások - jelen esetben oktatás - tervezését, irányítását és ellenőrzését, míg a mikrostruktúrának tekinthető szakképző intézmények pedig a szakoktatás operatív megvalósítását végzik el. A köztes szuperstruktúrának tekinthető NSZFH és szakképzési centrumok a mikrostruktúrák szintjén elhelyezkedő szakképző intézmények egységes irányítását is végezik a hierarchia csúcsán álló szuperstruktúra irányítása és kontrollja mellett.

A közszolgálati szervezetek öt szektorszintû modelljeit számba véve azt a következtetést vonjuk le, hogy szakképzés intézményrendszerének szektor szintû irányítása a gépmodell mintájára múködik. Ez leginkább abban nyilvánul meg, hogy a törvények, rendeletek, szabályzatok mind a szuper (Fenntartó, NSZFH, Szakképzési centrum)- és mikrostruktúra (Szakképző intézmény) szintjén érvényesek. A törvények, rendeletek pontosan meghatározzák az egyes szervezeti egységek múködését, szerepüket, feladataikat, véleményezési, döntés-elókészítési és döntési hatáskörüket. A gépmodellben a folyamatos ellenőrzés a múködés meghatározó jellemzője, ugyanakkor meghatározója az egyéni kezdeményezések letörése. A 21. század változó világában fel kell tennünk azt a kérdést, hogy a rendkívüli rugalmasságot és átalakulást átélő ipar és szolgáltatási szektor számára munkerô utánpótlást biztosító képzések világában valóban a leghatékonyabb múködési módként tekinthetünk a rugalmatlanságáról elhíresült gépmodell szerinti múködési módra? 


\section{FELHASZNÁLT IRODALOM}

1. 2011. évi CXC. törvény a nemzeti köznevelésről. Elérhető: https://net.jogtar.hu/jogszabaly?docid=a1100190.tv (Hozzáférés dátuma: 2021.09.15.)

2. 319/2014. (XII.13.) kormányrendelet a Nemzeti Szakképzési és Felnőttképzési Hivatalról. Elérhető: https:// net.jogtar.hu/jogszabaly?docid=A1400319.KOR\&timeshift $=20170$ 101\&txtreferer=A1100187.TV (Hozzáférés dátuma: 2021.10.09.)

3. 2015. évi LXVI. törvény a szakképzésről szóló 2011. évi CLXXXVII. törvény, a felnőttképzésről szóló 2013. évi LXXVII. törvény és az azokkal összefüggő tárgyú törvények módosításáról. Elérhető: https://net.jogtar.hu/jogszabaly?docid=A1500066.TV\&timeshift $=2016090$ 1 \&txtreferer=A1400099.TV (Hozzáférés dátuma: 2021.10.03.)

4. 120/2015. (V.21.) kormányrendelet a Klebelsberg Intézményfenntartó Központ fenntartásában múködő egyes szakképzési feladatot ellátó köznevelési intézmények fenntartóváltásával összefüggő intézkedésekről. Elérhetô:

https:// net.jogtar.hu/jogszabaly?docid=A1500066.TV\&timeshift $=2016090$ 1\&txtreferer=A1400099.TV (Hozzáférés dátuma: 2021.10.04.)

5. 146/2015. (VI. 12.) kormányrendelet a Klebelsberg Intézményfenntartó Központ fenntartásában múködő egyes szakképző intézmények átadásáról, valamint egyes kormányrendeleteknek a szakképzés intézményrendszerének átalakításával összefüggő módosításáról. Elérhető:

https://net.jogtar.hu/jogszabaly?docid=A1500146.KOR\&txtreferer $=00000$ 001.TXT (Hozzáférés dátuma: 2021.10.08.)

6. 18/2016. (X. 12.) NGM utasítás a Nemzeti Szakképzési és Felnőttképzési Hivatal Szervezeti és Múködési Szabályzatáról. Elérhető: https:// net.jogtar.hu/getpdf?docid=A16U0018.NGM\&targetdate=fffffff4 \&printTitle $=18 / 2016 .+\% 28 \mathrm{X} .+12 . \% 29+\mathrm{NGM}+\mathrm{utas} \% \mathrm{C} 3 \% \mathrm{ADt} \% \mathrm{C} 3 \% \mathrm{~A} 1$ s\&referer=http $\% 3 \mathrm{~A} / /$ net.jogtar.hu/jr/gen/hjegy doc.cgi $\% 3$ Fdocid $\% 3 \mathrm{D} 0$ 0000001.TXT (Hozzáférés dátuma: 2021.10.08.)

7. 2019. évi LXXX. törvény a szakképzésről. Elérhető: https://net.jogtar.hu/jogszabaly?docid=a1900080.tv (Hozzáférés dátuma: 2021.10.09.)

8. 12/2020. (II.7.) kormányrendelet a szakképzésről szóló törvény végrehajtásáról. Elérhető:

https://net.jogtar.hu/jogszabaly?docid=a2000012.kor 
(Hozzáférés dátuma: 2021.10.09)

9. Antal, Zs., Drótos, Gy., Kiss, N., Kováts, G., Révész, É. \& Varga-Polyák Cs. (2011): Közszolgálati szervezetek vezetése. Budapesti Corvinus Egyetem. Aula Kiadó. Budapest.

10. Antal Zs., \& Dobák, M. (2016): Vezetés és szervezés: szervezetek kialakítása és múködtetése. Akadémiai Kiadó. Budapest.

11. Bakacsi, Gy. (2006): Szervezeti magatartás és vezetés. Budapest, Aula.

12. Benedek, I. (1998): Feladatok, kompetenciák változása az intézményvezetői gyakorlatban. Új Pedagógiai Szemle, 48(10), pp. 20-29.

13. Barnard, C. I. (1938): The Functions of the Executive. Cambridge, Mass.: Harvard University Press.

14. Bolman, L. G., \& Deal, T. E. (2017): Reframing organizations: Artistry, choice, and leadership. 6th edition. John Wiley \& Sons.

Elérhető:

https://books.google.hu/books?hl=hu\&lr=\&id=1PLCDwAAQBAJ\&oi=f nd\&pg $=$ PR9\&dq $=$ Bolman,+ L. $+\% 26+$ Deal,+ T. $+(1997)+$ Reframing + orga nizations\&ots $=$ pbALgNhzPX\&sig $=u J G \quad C m e L Q j A O n B s S n P N K W-$

jWaVs\&redir esc $=_{\mathrm{y}} \#_{\mathrm{v}}=$ onepage $\& \mathrm{q}=$ Bolman $\% 2 \mathrm{C} \% 20 \mathrm{~L} . \% 20 \% 26 \% 20 \mathrm{Dea}$ 1\%2C\%20T.\%20(1997)\%20Reframing $\% 20$ organizations\&f=false

(Hozzáférés dátuma: 2021.09.04)

15. Bowen, G. A. (2009): Document Analysis as a Qualitative Research Method. Qualitative Research Journal(1443-9883), 9(2), pp. 27-40. DOI:10.3316/QRJ0902027

16. Corbin, J. \& Strauss, A. (2008): Basics of qualitative research: Techniques and procedures for developing grounded theory (3rd ed.). Thousand Oaks, CA: Sage.

17. CSEPELI, Gy. (2015): A szervezkedő ember: A szervezeti élet szociálpszichológiája. Kossuth Kiadó.

Elérhető: $\quad$ https://books.google.hu/books?hl=hu\&lr=\&id=RQ6GCg $\underline{A A Q B A J \& O i}$

$=$ fnd\&pg $=$ PT4\&dq $=$ Csepeli $+\mathrm{Gy}:+\mathrm{A}+$ szervezked $\% \mathrm{C} 5 \% 91+$ ember\&ots $=\mathrm{k}$ Up5HjQ17\&sig $=$ HvQEciCQ2wuf9leJjTtZcmanLGM\&redir esc $=\mathrm{y} \# \mathrm{v}=$ on epage\&q $=$ Csepeli $\% 20 \mathrm{~Gy} \% 3 \mathrm{~A} \% 20 \mathrm{~A} \% 20$ szervezked $\%$ C5 $\% 91 \% 20$ ember\&f =false (Hozzáférés dátuma: 2012.04.02)

18. Dennision, W. F. (2018): Educational finance and resources. Routledge.

19. Dobák, M. \& Antal, Zs. (2018): Vezetés és szervezés. Szervezetek kialakítása és múködtetése. Akadémiai Kiadó, Budapest. 
Elérhető: https://mersz.hu/dokumentum/dj147vesz 2 (Letöltés ideje: 2021.04.02)

20. Farkas, Z. (2007): Az intézmény fogalma, fedezete és formalitása. Miskolci Jogi Szemle 2. évf. 2. sz. pp. 33-55.

Elérhetô: $\quad$ http://midra.uni-miskolc.hu/document/12637/4713.pdf (Hozzáférés dátuma: 2021.04.05)

21. Farkas, Z. (2010): Az intézmények fố típusai: a közösségi, a társadalmi és a testiségi intézmények. Kulturra és köoösség. Felnöttoktatás, felnôttkeépzés. 1/14(1) pp. 87-101.

Elérehtő: $\quad$ https://www.researchgate.net/publication/316275074 Az intezmenyek fo tipusai a kozossegi a tarsadalmi es a testisegi inte zmenyek/link/58f88ffaa6fdcc3098d8e472/download (Hozzáférés dátuma: 2021.04.05.)

22. Györgyi, Z. (2019): Célok és következmények: tanügyirányításunk átalakítása. Educatio, 28 (2), pp. 211-227.

Elérhető: https://doi.org/10.1556/2063.28.2019.2.1 (Hozzáférés dátuma: 2021.08.16.)

23. Halász, G. (2001): Az oktatási rendszer. Múszaki Könyvkiadó, Budapest

24. Keczer, G. (2014): Management and organizational characteristics of educational institutions. Education Practice and Innovation, 1(2). pp. 106112 https://doi.org/10.15764/epi.2014.02011

25. Mártonfi, Gy. (2016): A szakképzés intézményrendszerének átalakulásai. Educatio, 2016(1), pp. 46-58.

26. Mártonfi, Gy. (2019): Tanügyirányítás és struktúraváltás a hazai szakképzésben 2010 után. Educatio, 28(2), pp. 240-254. Elérhető: https://doi.org/10.1556/2063.28.2019.2.3 (Hozzáférés dátuma: 2020.09.15)

27. Metz, R. (2020): Az elefánt a szobában: A vezetés jelentősége a közszektorban. Politikatudomány (online), 8(2), pp. 1-19.

28. Mintzberg, H. (1996): Managing government, governing management. Harvard business review, 74 (3), 75.

Elérhetô: $\quad$ https://hbr.org/1996/05/managing-government-governingmanagement (Hozzáférés dátuma: 2021.09.04.)

29. Móré, M. \& Kozák, A. (2015): "Menedzsment feladatok a közoktatási intézményekben." In: Szilágyi, B., Mező, K., \& Mező, F. (szerk.) Az együttnevelés útjai: pp. 189-204.

30. Palumbo, R. \& Manna, R. (2019): Making educational organizations able to change: a literature review. International Journal of Educational Management. 33(4), 
pp. 734-752. Elérhetô: $\quad$ https://doi.org/10.1108/IJEM-02-2018-0051 (Hozzáférés dátuma: 2021.09.24.)

31. Pierog, A. \& Szabados, K. (2015): Szervezet - változtatás és fejlesztés - a helyzetfelmérés során Alkalmazott módszerek = Organizational Change and Development - Methods for the Taking. Taylor, 7(1-2), pp. 51-57.

Elérhető: http://vikek.eu/wp-content/uploads/2015/10/TAYLOR 2015nyomdai.pdf(Hozzáférés dátuma: 2021.04.04)

32. Rainey, H. G. (2009): Understanding and managing public organizations. John Wiley \& Sons.

33. Rapley, T. (2007): Doing conversation, discourse and document analysis. London: Sage

34. Rónay, Z. (2019): A hazai tanügyigazgatás jogszabályi keretei. Educatio, 28(2), pp. 228-239. DOI: 10.1556/2063.28.2019.2.2

35. Roper, L. D., \& Whitt, E. J. (2016): What troubles you? What keeps you up at night? New Directions for Student Services, 2016(153), pp. 19-37.

36. Váradi, L. (2009): A művelődésigazgatás kézikönyve. HVG-ORAC. Budapest.

37. Weber, M. (1987). Gazdaság és társadalom: A megértő szociológia alapvonalai. Közgazdasági és Jogi Könyvkiadó. Budapest.

38. Szakképzés Információs Rendszere (2021). Elérhető: https://szir.nive.hu/publikus/intezmeny-listazo. (Hozzáférés dátuma: 2021.11.26.) 
ISSN 2630-886X

18 国 57
BGE 